\title{
HEGEMONI KERJA IMATERIAL SEBAGAI PELUANG RESISTENSI TERHADAP KAPITALISME DALAM PERSPEKTIF AUTONOMIA
}

\begin{abstract}
A. Galih Prasetyo*
Abstrak: Kapitalisme kontemporer dicirikan oleh beberapa transformasi makro-struktural, seiring dengan kemajuan teknologi informasi dan komunikasi. Salah satu dari transformasi paling drastis terjadi di dalam aktivitas kerja. Sebagai aktivitas utama yang mendorong akumulasi modal, dunia kerja hari ini ditandai oleh hegemoni kerja imaterial. Artikel ini menyajikan pikiran dan gagasan dari Autonomia, sebuah "aliran pemikiran" kontemporer dari Italia yang merenungkan sifat dan karakter dari jenis kerja "baru" tersebut. Para pemikir Autonomia berargumen bahwa hegemoni kerja imaterial memberikan tantangan dan peluang baru dalam tatanan kapitalisme. Sementara pekerja imaterial rentan untuk dieksploitasi oleh pihak kapitalis, mereka juga dapat membebaskan dirinya dari penindasan kapitalis. Hal ini dimungkinkan karena kerja imaterial memuat karakteristik khusus dalam kaitannya dengan modal. Emansipasi dari relasi kapitalis dapat terjadi apabila pekerja imaterial, bersama dengan korban kapitalisme lainnya, bersatu sebagai jaringan jamak dan melakukan dua strategi perlawanan: penolakan kerja dan eksodus.
\end{abstract}

Kata-kata Kunci: Kerja imaterial, Autonomia, kapitalisme, jaringan jamak, penolakan kerja, eksodus.

Abstract: Contemporary capitalism is characterized by some macrostructural transformations, along with the advancement of information and communication technologies. One of the most drastic transformations occurs in the nature of labor. As the main activity which drives the accumulation of capital, today's labor world is marked by the hegemony of immaterial labor. This article presents thoughts and ideas of Autonomia, a contemporary "school of thought" originating from Italy which has a

* A. Galih Prasetyo, Pascasarjana Sosiologi, Fakultas Ilmu Sosial dan Ilmu Politik, Universitas Gadjah Mada, Jl. Sosio Yustisia, Yogyakarta. E-mail:antgalihprasetyo@gmail.com. 
distinctive view on traits and characters of this "new" kind of labor. Autonomia thinkers argue that the hegemony of immaterial labor poses new challenges and opportunities within capitalist order. While immaterial laborers are prone to be exploited by capitalists, they also can liberate themselves from the capitalist oppression. It is because immaterial labor embodies special characteristics in its relation to capital. The emancipation from capitalist relations can happen if immaterial laborers, together with other capitalism's victims, unite as a multitude and enforce two resistance strategies, namely, refusal of work and exodus.

Keywords: Immaterial labor, Autonomia, capitalism, multitude, refusal of work, exodus.

\section{PENDAHULUAN}

Sebagai modus tindakan manusia yang paling eksistensial, kerja mempunyai peran yang konstitutif dalam upaya manusia menegaskan identitasnya. Identitas manusia ditunjukkan secara nyata di dalam kerja karena kerja merupakan respons yang khas dari manusia dalam menanggapi determinasi alamiah yang dibebankan kepada dirinya. Akan tetapi, kerja bukan semata kebutuhan universal manusia dalam tataran fisis dan biologis sebab kerja juga bagian dari cara manusia mentransendensikan dirinya dari alam melalui pendayagunaan kemampuan imajinatif, estetis, etis, dan spiritual. Dalam hal ini, cara seseorang menjalankan laku kerja akan merefleksikan secara efektif karakter, kepribadian, dan aspirasi dari subjek manusia yang bersangkutan.

Dalam dunia modern, hubungan antara kerja dengan kemanusiaan seringkali menjadi kabur oleh fakta bahwa kerja telah menjadi kesadaran praktis dari kebanyakan manusia. Sebagian besar waktu yang dijalani manusia modern dihabiskan untuk bekerja sehingga hampir seluruh kesadaran mental, keprihatinan, dan cita-cita manusia modern selalu terkait dengan hal-hal yang tidak jauh dari urusan pekerjaan. Fakta ini menunjukkan dengan gamblang betapa masyarakat, baik yang berada di negara maju maupun berkembang, telah menjadikan kerja sebagai poros utama dari tindakan dan bahkan hidupnya. Arus besar moderni- 
sasi yang berkembang sejak dimulainya Revolusi Industri pada pertengahan abad ke-18 dan menyebar secara perlahan namun pasti ke seluruh dunia telah menjadikan kerja sebagai etos utama kemanusiaan yang berperan sebagai lokomotif pendorong bagi pemajuan kehidupan masyarakat melalui berbagai upaya pembangunan dan industrialisasi.

Di era yang lebih kontemporer, kerja bahkan terasa sebagai suatu hal yang ditemui dan dijalani di mana-mana. Hampir seluruh aktivitas dan tindakan manusia dewasa ini terklasifikasikan sebagai bagian dari kerja. Kerja tidak lagi hanya dapat ditemui di pabrik atau bengkel-bengkel industri seperti pada masa-masa awal industrialisasi. Kerja dalam era kekinian juga dapat ditemui di jalan raya, trotoar, gedung-gedung komersial, lembaga birokrasi dan politik, bahkan di dalam rumah. Berbagai perubahan penting yang terjadi dalam beberapa dekade terakhir, khususnya kemajuan pesat teknologi informasi, komunikasi, dan perhubungan, memainkan peran yang penting dalam memacu penghadiran masif kerja dalam seluruh ranah sosial tersebut.

Melalui hegemoni kerja dalam dunia kontemporer tersebut, kerja seolah diangkat statusnya dalam tataran pseudo-spiritual melalui pengagungan yang hiperbolis atasnya. Kita dapat melihat fenomena ini dalam berbagai manifestasi seperti banyaknya pekerja yang mengalami kecanduan kerja atau workaholic, retaknya keluarga-keluarga di perkotaan besar dan penelantaran anak akibat kesibukan orang tua yang bekerja dari pagi sampai malam, maraknya motivator, buku, dan seminar yang memberikan tips dan penguatan bagi kaum pekerja agar lebih sukses mengembangkan karirnya, sengitnya persaingan untuk naik jabatan dan mendapat promosi melalui rupa-rupa intrik politik kantor, dan membludaknya peminat atas pekerjaan-pekerjaan yang dianggap bergengsi.

Dalam berbagai fenomena tersebut, kerja dihargai secara fiksatif. Masyarakat kontemporer digiring kepada suatu kondisi yang memungkinkan terjadinya pelupaan atas hakikat dari kerja. Kerja sesungguhnya hanyalah salah satu dari tindakan-tindakan khas manusia yang luas 
seperti bermain, beristirahat, bersosialisasi, berpolitik, dan berkesenian. Namun kini seluruh aktivitas tersebut dikebawahkan atau dibingkai dalam paradigma kerja: beristirahat untuk mendapatkan kesegaran yang cukup agar dapat bekerja dengan lebih keras, bersosialisasi agar mendapatkan jaringan strategis yang meningkatkan peluang dalam membangun karir yang sukses, dan sebagainya. Dalam iklim kultural seperti ini, segala hal yang tidak terklasifikasikan sebagai kerja direndahkan status dan derajatnya. Mereka yang menjadi pengangguran dianggap sebagai sampah masyarakat, tanpa mempertimbangkan berbagai faktor yang menyebabkan terjadinya pengangguran tersebut.

Berbagai fenomena di atas merupakan contoh dari perubahan kualitatif mendasar terhadap aktivitas yang kita sebut "kerja." Kerja telah mengalami perubahan paradigmatik dalam suatu cara yang memaksa kita untuk mempertimbangkan dan meredefinisi pengertian kerja itu sendiri. Salah satu perubahan yang paling mencolok adalah fakta bahwa kerja kini semakin disadari memiliki dimensi politik yang kuat. Dimensi politik tersebut diturunkan dari kenyataan mengenai semakin banyaknya waktu hidup yang digunakan untuk bekerja dan semakin luasnya jenis-jenis aktivitas yang kini digolongkan sebagai kerja, sebagaimana terlihat jelas melalui contoh-contoh yang telah diuraikan di atas. Dalam perspektif yang lebih tegas, dapat dikatakan bahwa kerja kini telah meresapi seluruh sektor kehidupan, termasuk politik. Terdapat relasi timbalbalik di sini. Problematika dan pertanyaan yang ada dalam dunia kerja sesungguhnya tak lain merupakan problematika dan pertanyaan politik. Kategori, norma, dan tindakan yang dijalankan dalam ranah politik kini semakin mengadopsi aturan main yang biasanya ada dalam ranah kerja.

Salah satu pandangan teoretis kontemporer yang mampu menganalisis secara tajam dan jenial tentang dimensi politik dari kerja tersebut datang dari gerakan intelektual yang disebut Autonomia, atau yang sering juga disebut dengan Operaismo dan workerism. Gerakan yang lahir di Italia ini melahirkan tradisi pemikiran kiri dengan tokoh-tokoh seperti Mario Tronti, Antonio Negri, Sergio Bologna, Franco Piperno, Oreste 
Scalzone, Franco Berardi "Bifo," Paolo Virno, dan Maurizio Lazaratto. Autonomia mengajukan penafsiran kembali atas pemikiran Karl Marx. For-mulasi pemikiran yang diajukannya tidak berkorespondensi dengan tradisi Marxisme Barat, melainkan berdasarkan interpretasi atas dina- mika konflik kelas yang terjadi di Italia setelah masa transisi yang terjadi pasca Perang Dunia II. ${ }^{1}$ Aliran pemikiran ini berakar pada sebuah gera- kan politik yang muncul pada awal tahun 1950-an di Italia. Pada masa itu, para pekerja imigran dari selatan yang bekerja di pabrik-pabrik besar yang ada di Italia Utara melakukan penentangan terhadap serikat buruh, Partai Komunis Italia, dan negara melalui berbagai aksi kolektif seperti autoreduksi dan sabotase produksi. Mereka kemudian mengorgani-sasikan diri ke dalam berbagai organ dan gerakan yang bernaung secara nasional melalui kelompok yang disebut dengan Potere Operaio (artinya "kekuatan pekerja"). ${ }^{2}$ Gerakan ini semakin berkembang dan kemudian terpecah-belah ke dalam berbagai faksi, termasuk kelompok perlawanan bersenjata Brigade Merah, sampai akhirnya mereka bubar di awal tahun

1980-an karena represi yang keras dari pemerintah Italia, yang membuat banyak aktivis dan pemikir Autonomia menjadi tahanan politik atau kabur ke luar negeri.

Melalui berbagai tulisan dari para pemikirnya, mazhab Autonomia berusaha mengungkapkan sifat-sifat dasar dari kerja di era globalisasi yang sering disebut era jejaring, post-modern, atau kapitalisme lanjut. Hal yang menarik dari pandangan mereka tentang kerja adalah bahwa kerja di era kontemporer berbeda secara paradigmatis dibandingkan dengan bentuk-bentuk kerja di masa lalu sehingga tidak ada preseden- nya. Kerja bentuk baru tersebut disebut dengan "kerja imaterial." Bagi

1 Adelino Zanini, “On the 'Philosophical Foundations' of Italian Workerism: A Conceptual Approach," Historical Materialism 18 (2010): 43.

2 Sylvere Lotringer and Christian Marazzi. "The Return of Politics" in Autonomia: Post-Political Politics, eds. Sylvere Lotringer and Christian Marazzi (New York: Semiotext(e), 1980), p. 9. Lebih jauh tentang gerakan ini, termasuk pembabakan periode historis yang dilaluinya serta tema utama pemikiran 
yang berkembang dalam setiap periode historis, lih. Michael Hardt, "Introduction: Laboratory Italy" in Radical Thought in Italy: A Potential Politics, eds. Paolo Virno and Michael Hardt (Minneapolis and London: University of Minnesota Press, 1996), pp. 1-3. 
arus pemikiran ini, konsep kerja menempati peran yang sangat penting. Jika Adam Smith dan Karl Marx mengatakan bahwa kerja merupakan sumber dari segala kekayaan yang ada di masyarakat, mereka menarik kesimpulan yang lebih radikal bahwa kerja merupakan sumber dari sosialitas itu sendiri, dalam mana segala relasi sosial dirajut. Kriteria kerja tidak ditentukan oleh apakah kerja tersebut dibayar atau tidak, melainkan merujuk pada seluruh potensi kreatif dari kapasitas praktis manusia. ${ }^{3}$ Karena sifat fundamental tersebut, kerja merupakan kunci untuk mema-hami segala problematika sosial, politik, ekonomi, dan kultural.

Dalam lanskap filsafat dan teori sosial kontemporer, pemikiran yang lahir dalam tradisi Autonomia memang kurang dikenal apabila dibandingkan dengan pemikiran yang lahir di Perancis dan Jerman, yang berturut-turut melahirkan tradisi pemikiran post-modern dan kritis. Tradisi Autonomia baru mulai masuk ke dalam gelanggang arus utama pemikiran kontemporer sejak penerbitan buku Empire (2000) oleh Michael Hardt dan Antonio Negri. ${ }^{4}$ Dengan menatapkannya terhadap realitas kontemporer, keduanya membarui dan mensofistikasi pemikiran awal Autonomia dan menunjukkan relevansinya bagi kondisi dunia dewasa ini. Buku tersebut mengundang debat yang keras di kalangan akademis, terutama yang berhaluan kiri, karena caranya yang segar dan provokatif dalam membaca realitas kapitalisme dan globalisasi kontemporer. ${ }^{5}$ Buku yang sering disebut-sebut sebagai Manifesto Komunis

3 Michael Hardt, Introduction, p. 5.

4 Antonio Negri merupakan akademisi cum aktivis yang merupakan bagian dari gerakan Autonomia awal tahun 1960-an. Ia pernah dipenjara di negerinya dan menjalani pengasingan di Paris akibat aktivitas politiknya di masa itu. Sementara Michael Hardt adalah bekas mahasiswanya yang kini menjadi professor di Duke University. Empire adalah karya kolaborasi mereka yang kedua. Sebelumnya mereka telah menulis Labor of Dionysus: A Critique of the State-Form (Minneapolis and London: University of Minnesota Press, 1994). Gagasan-gagasan yang termuat dalam buku tersebut muncul kembali dalam bentuk yang lebih canggih dan kontemporer, terutama mengenai kritiknya terhadap negara.

5 Terdapat satu buku utuh yang berisi tanggapan-tanggapan kritis terhadap buku Empire, yakni Debating Empire, edited by Gopal Balakrishnan (London and New York: Verso, 2003). 
untuk abad 21 tersebut merupakan bagian pertama dari trilogi yang disusul berturut-turut dengan penerbitan Multitude (2004) dan Commonwealth (2009).

Seiring dengan semakin nyatanya prediksi yang diajukan dan polapola yang digariskan dalam tulisan para pemikirnya, gagasan Autonomia kini menjadi semakin dikenal, baik dalam diskursus akademis maupun aktivisme. Tulisan ini berupaya untuk melakukan penelaahan terhadap pemikiran yang bersumber dari tradisi Autonomia. Penulis tidak akan membahas seluruh teori dari tradisi Autonomia yang sangat kaya, melainkan memfokuskannya hanya pada teori kerja imaterial dan konsepkonsep yang terkait dengannya. Tulisan diorganisasikan dalam alur berikut ini. Setelah dibuka dengan bagian Pendahuluan, tulisan akan dilanjutkan dengan pemaparan mengenai kondisi struktur kerja global dewasa ini yang dicirikan dengan hegemoni kerja imaterial. Selanjutnya, penulis akan membahas mengenai hubungan yang unik antara kerja imaterial dengan kapitalisme kontemporer. Di satu sisi, berkat kerja imaterial kapitalisme mampu meluaskan ranah produksinya hingga mencakup seluruh kehidupan sosial. Namun di sisi lain, hegemoni kerja imaterial juga menyajikan tantangan berat terhadap kapitalisme sampai dalam tataran di mana kapitalisme dapat lumpuh karenanya. Pelumpuhan terhadap kapitalisme tersebut hanya mungkin apabila para korban kapitalisme bekerjasama membentuk subjek politik revolusioner baru yang disebut "jaringan jamak" (multitude). Tema jaringan jamak ini akan menjadi pokok bahasan dalam bagian selanjutnya sebelum tulisan diakhiri dengan bagian Penutup.

\section{HEGEMONI KERJA IMATERIAL DALAM PARADIGMA EKONOMI POST-MODERN}

Dengan merunut kepada sejarah yang berlangsung dari Abad Pertengahan sampai dewasa ini, Hardt dan Negri membagi paradigma ekonomi ke dalam tiga tahapan, di mana masing-masing tahapan mempunyai sektor ekonomi dominan yang berbeda. Paradigma pertama ditandai oleh dominasi sektor agrikultur dan ekstraksi material alami, 
dilanjutkan dengan paradigma kedua berupa dominasi industri dan manufaktur barang-barang tahan lama, dan ditandai paradigma ketiga dengan dominasi jasa dan manipulasi informasi dalam kehidupan ekonomi. Berturut-turut, peralihan paradigma ekonomi tersebut memperlihatkan bahwa dominasi kegiatan ekonomi cenderung beralih dari produksi barang primer menuju barang sekunder dan akhirnya barang tersier. Apabila peralihan dari paradigma pertama ke paradigma kedua sering disebut "lahirnya era modernisasi" atau "industrialisasi ekonomi," maka peralihan dari paradigma kedua ke paradigma ketiga dapat disebut "postmodernisasi atau informatisasi ekonomi." ${ }^{6}$

Hal yang patut diperhatikan di sini adalah bahwa peralihan dari satu paradigma ke paradigma lain tersebut hendaknya tidak dimengerti dalam dimensi kuantitatif, melainkan kualitatif. Memandang peralihan tersebut semata dari perspektif kuantitatif (jumlah total tenaga kerja dan jumlah total nilai yang diproduksi dalam sektor ekonomi dominan) akan membuat kita gagal melihat transformasi kualitatif yang terjadi melalui transisi paradigma. Dalam peralihan dari dominasi agrikultur ke industri, misalnya, peralihan yang terjadi tersebut ditandai bukan pertama-tama oleh turunnya jumlah pekerja yang bekerja di dalam sektor agrikultur (meskipun ini memang juga terjadi di banyak wilayah dan negara), melainkan oleh berubahnya sifat dari kegiatan agrikultur yang dilakukan. Sektor agrikultur tidak hilang dalam era ini, melainkan dijalankan seturut norma-norma yang berlaku di zaman industri, yang memaksa produksi agrikultur (dan juga kehidupan sosial secara umum) menjadi terindustrialisasikan. Selain itu, dengan memandang peralihan paradigma tersebut secara kualitatif, kita akan mendapatkan gambaran tentang relasi kekuasaan hierarkis yang eksis dalam sistem ekonomi global. Dengan gambaran tersebut, fakta bahwa produksi agrikultur de facto menjadi sektor ekonomi yang dominan di beberapa negara berkembang tidak dapat dianalogikan dengan kondisi pra-industrial. Dalam perspektif relasi kuasa global, fakta tersebut hanya menunjukkan bahwa

6 Michael Hardt and Antonio Negri, Empire (Cambridge, MA, and London: Harvard University Press, 2000), p. 280. 
produksi agrikultur yang dominan di negara-negara berkembang tersebut menempati posisi yang tersubordinasi oleh dominasi sektor industri dalam sistem ekonomi global. ${ }^{7}$

Dewasa ini, modernisasi telah selesai dan kita telah memasuki paradigma ketiga, yakni ekonomi post-modern. Dalam era ini, sektor ekonomi berbasis jasa dan informasi menjadi sektor yang hegemonis. Sekali lagi, pernyataan tersebut hendaknya dipahami secara kualitatif. Dominasi ekonomi jasa dan informasi tidak perlu dicapai melalui suatu urutan historis yang linier. Sebuah negara dapat melakukan transformasi langsung dari dominasi ekonomi agrikultur ke ekonomi jasa, seperti kasus Italia. Demikian pula sebuah negara bisa saja menyelenggarakan tiga model sektor ekonomi secara simultan seperti yang terjadi di India, Brasil, dan Indonesia. Semua jenis produksi tersebut eksis secara simultan di dalam jaringan pasar dunia dan di bawah dominasi produksi informasi dan jasa. ${ }^{8}$

Perubahan menuju paradigma ekonomi post-modern membawa pula perubahan pada kualitas dan sifat dari kerja. Kerja yang dilakukan dalam era ekonomi post-modern disebut "kerja imaterial." Menurut Hardt dan Negri, kerja imaterial adalah kerja yang memproduksi barangbarang imaterial seperti pengetahuan, informasi, komunikasi, relasi, atau respons emosional. ${ }^{9}$ Banyak di antara jenis pekerjaan yang tergolong

7 Michael Hardt and Antonio Negri, Empire, pp. 281-282.

8 Michael Hardt and Antonio Negri, Empire, pp. 288-289. Pandangan yang berbeda diajukan oleh David Harvey. Menurutnya, ekonomi post-fordis tidak menempati posisi hegemonis di mana pun di era kontemporer. Model produksi global saat ini ditandai oleh campuran dari produksi Fordis (yang telah menggunakan prinsip teknologi dan output fleksibel) yang mencolok di beberapa sektor dan negara (misalnya, sek- tor otomotif di Amerika Serikat, Jepang, dan Korsel) dengan sistem produksi tradi- sional yang dicirikan oleh hubungan kerja yang bersifat artisan, paternalistik, dan patriarkalfamilial. Sejak 1970, justru sistem produksi terakhir itulah yang semakin berkembang, termasuk di negara-negara kapitalis termaju, kadangkala dengan kor- ban berupa hilangnya pabrik-pabrik model fordis. Lih. David Harvey, The Con- dition of Postmodernity: An Enquiry into the Origins of Cultural Change (Cambridge, MA, and Oxford: Blackwell, 1990), p. 191.

9 Michael Hardt and Antonio Negri, Multitude: War and Democracy in the Age of Empire (New York: Penguin Press, 2004), p. 108. Definisi lain diberikan oleh Maurizio Lazzarato. Menurutnya, kerja imaterial adalah "kerja yang memproduksi isi infor-masional 
imaterial membutuhkan mobilitas dan fleksibilitas yang tinggi, seperti pelayanan kesehatan, pendidikan, keuangan, transportasi, hiburan, dan periklanan. ${ }^{10}$ Dalam sosok pekerja imaterial, batasan lama yang biasa membedakan antara pekerja mental versus manual, pekerja intelek-tual versus fisik, dan pekerja individual versus kolektif, tidak dapat lagi dipertahankan karena semua kategori tersebut kini menyatu ke dalam kerja imaterial. ${ }^{11}$ Dalam melakukan kerjanya, pekerja imaterial mengerahkan secara sekaligus berbagai macam kemampuan, baik kemampuan intelektual, kemampuan manual, maupun kemampuan wirausaha. ${ }^{12}$

Memang terdapat ambiguitas yang terkandung di dalam istilah kerja imaterial sehingga perlu dilakukan klarifikasi atasnya. Kerja yang tergolong dalam kerja imaterial tetaplah bersifat material, yakni melibatkan tubuh dan otak sebagaimana kerja material. Kerja imaterial juga dilakukan menggunakan alat-alat material (perawat, misalnya, dalam bekerja menggunakan perban). ${ }^{13}$ Apa yang bersifat imaterial, sekali lagi, adalah produknya. Pada dirinya produk ini tidak dapat dihabiskan melalui konsumsi sekali untuk selamanya. Akan tetapi, produk kerja imaterial justru memperluas, mentransformasi, dan menciptakan lingkungan "ideologis" dan kultural dari konsumen. Dengan kata lain, produk kerja imaterial mentransformasi orang yang menggunakannya. ${ }^{14}$

dan kultural dari komoditas." Lih. Maurizio Lazzarato, "Immaterial Labor," in Radical Thought in Italy, p. 132. Dalam tulisan ini, apabila ditulis kerja imaterial, yang dimaksud adalah definisi yang dipakai Hardt dan Negri. Sementara istilah kerja immaterial sendiri digunakan pertama kali oleh Henri Storch pada awal abad ke-19. Istilah ini digunakannya untuk menyanggah gagasan Adam Smith bahwa kerja yang dilakukan oleh sebagian kaum elit masyarakat tidak memiliki nilai produktif. Lih. Wolfgang Fritz Haug, "Immaterial Labour," Historical Materialism 17 (2009): 177.

10 Thomas Atzert, "About Immaterial Labor and Biopower," Capitalism, Nature, Socialism, 17/1 (2006): 60 .

11 Thomas Atzert, "About Imaterial Labor and Biopower": 61; Maurizio Lazzarato, "Immaterial Labor," p. 133. Bdk. Christian Marazzi, Capital and Language: From the New Economy to the War Economy (Los Angeles: Semiotext(e), 2008) yang berbicara tentang runtuhnya distingsi antara ekonomi riil dan ekonomi spekulatif (misalnya, ekonomi yang dijalankan via pasar finansial) karena keduanya kini dipengaruhi erat oleh bahasa dan komunikasi.

12 Maurizio Lazzarato, Immaterial Labor, p. 136.

13 Michael Hardt and Antonio Negri, Multitude, p. 109.

14 Maurizio Lazzarato, Immaterial Labor, p. 137. 
Hegemoni kerja imaterial dimungkinkan karena adanya suatu perubahan struktural besar dalam model produksi, yakni dari model "fordisme" ke "post-fordisme" atau yang sering juga disebut "toyotisme." Perubahan model produksi ini juga merupakan salah satu manifestasi dari perubahan paradigma ekonomi dari modern ke post-modern. Fordisme merujuk pada gagasan, prinsip, dan sistem yang dikembangkan oleh industriawan Henry Ford, pencipta mobil Ford, pada awal abad ke-20. Ford mengembangkan sistem produksi massal modern, terutama melalui metode sistem perakitan mobil secara bergilir (assembly line). Secara teoretis, fordisme adalah rezim akumulasi distingtif yang dikembangkan sebagai strategi politik oleh negara-negara industrial maju pasca Perang Dunia II, di mana koorporasi bekerjasama dengan negara untuk menstabilkan kapitalisme. Fordisme menjadi dominan pada kurun waktu 1945-1973, ketika pertumbuhan ekonomi di negara kapitalis maju tumbuh secara cepat dan stabil. ${ }^{15}$

Namun sejak akhir 1960-an, stabilitas dari sistem fordisme sebenarnya sudah mulai goyang. Destabilisasi tersebut dipicu oleh berbagai perkembangan penting dalan sistem ekonomi politik global, seperti melemahnya kekuatan Amerika, dicabutnya sistem Bretton Woods tahun 1971-1973, dan melonjaknya harga minyak dunia pada 1973. Turunnya pertumbuhan ekonomi dan resesi ekonomi yang terjadi pada tahun 1970an dan 1980-an menciptakan keresahan sosial dan penguatan militansi pekerja di mana-mana. Inilah konteks yang mendasari urgensi untuk mengembangkan sistem produksi baru, karena melalui berbagai perkembangan tersebut tersingkaplah betapa sistem produksi fordisme tidak lagi menguntungkan dan efektif. ${ }^{16}$

Secara khusus, sistem produksi industrial yang dikembangkan di Jepang seringkali dirujuk sebagai contoh dari praktik produksi postfordis. Ketika krisis paradigma fordisme semakin mengemuka, berbagai

15 George Baca, "Legends of Fordism: Between Myth, History, and Foregone Conclusions" Social Analysis 48/3 (2004): 170-171.

16 Ray Kiely, "Globalization, Post-Fordism and the Contemporary Context of Development," International Sociology 13/1 (1998): 98. 
perusahaan berlomba-lomba untuk turut mengadopsi model Jepang agar dapat bertahan. Terdapat enam ciri dari sistem produksi Jepang: serikat kerja berbasis perusahaan yang pro manajemen dan terdepolitisasi, eskperimen teknik-teknik produksi yang dipicu oleh hambatan impor dan restriksi investasi asing, modifikasi dan inovasi terhadap teknologi impor, penciptaan produk yang beragam untuk melayani pasar yang relatif kecil, jaringan penyedia dan subkontraktor yang bekerjasama dalam jangka panjang dengan perusahaan inti, dan kehadiran firma manufaktur skala kecil dan menengah dalam jumlah banyak. ${ }^{17}$ Industri otomotif merupakan industri yang paling gencar mengadopsi norma-norma produksi baru tersebut. Salah satu industri ini adalah Toyota, yang menjelaskan mengapa post-fordisme seringkali juga disebut "toyotisme."

Post-fordisme pada dasarnya bukanlah suatu konsep yang dimengerti secara tunggal. Terdapat beberapa aliran yang berbicara tentang post-fordisme dengan titik penekanan dan model analisisnya masingmasing; misalnya, aliran regulasi (Bob Jessop, Alain Lipietz, Michel Aglietta), neo-schumpeterianisme (Carlota Perez, Michael Storper, Christoher Freeman), dan Autonomia. Namun di tengah berbagai perbedaan yang ada, semuanya setuju bahwa post-fordisme terutama berkenaan dengan produksi yang lebih fleksibel dan terspesialisasi. ${ }^{18}$ Akan tetapi, penggunaan konsep post-fordisme tidak terbatas pada perbincangan tentang aspek-aspek ekonomi seperti proses kerja dan organisasi produksi. Post-fordisme juga diasosiasikan dengan perubahan sosial dan kultural yang lebih luas, seperti meningkatnya fragmentasi dan pluralisme dalam masyarakat, pelemahan solidaritas kolektif lama, dan kemunculan bentuk-bentuk baru identitas yang diakibatkan oleh peningkatan fleksibilitas kerja dan pemaksimalan pilihan individu melalui konsumsi. ${ }^{19}$

17 Mitchell Bernard, "Post-Fordism, Transnational Production, and the Changing Global Political Economy" in Political Economy and the Changing Global Order, eds. Richard Stubbs \& Geoffrey R. D. Underhill (Hampshire \& London: Macmillan, 1994), p. 219.

18 Krishan Kumar, From Post-Industrial to Post-Modern Society: New Theories of the Contemporary World. Second Edition (Malden, Oxford \& Victoria: Blackwell Publishing, 2005), p. 71.

19 Stuart Hall, "Brave New World," Marxism Today, (October 1998): 24. Untuk diskusi yang lebih detail dan komprehensif mengenai post-fordisme dalam berbagai dimen- 
Sementara bila ditinjau dari sistem produksi, perbandingan antara sistem produksi fordis dan sistem post-fordis akan membawa kita kepada berbagai perbedaan fundamental sebagai berikut. Pertama, perubahan dalam sistem komunikasi yang terjadi antara produksi dan konsumsi komoditas, atau antara pabrik dengan pasar. Dalam model fordis, komunikasi antara produsen dan konsumen berlangsung secara kaku dan rigid. Produksi massal atas komoditas terstandar yang menjadi ciri khas fordisme diproduksi dalam kuantitas yang diperkirakan cukup sehingga tidak perlu "mendengarkan" pasar. Sirkuit umpan balik dari konsumsi ke produksi hanya mampu menciptakan perubahan yang terbatas dan lambat terhadap cara suatu produksi dijalankan akibat pembakuan saluran struktur perencanaan dan desain serta rigiditas dalam penggunaan teknologi dan prosedur produksi. Berbeda halnya dengan model post-fordis. Dalam model ini, relasi antara produksi dengan konsumsi yang ada dalam fordisme dibalik. Dalam tipe idealnya, produsen melakukan komunikasi dengan konsumen secara konstan dan langsung. Pabrik tidak menyimpan barang satu pun karena barang baru akan diproduksi setelah konsumen melakukan permintaan. Bahkan dalam kasus yang ekstrem, produksi baru akan dilakukan setelah konsumen memilih dan membeli produk yang dipilihnya. Meskipun tipe ideal tersebut kadangkala tidak ditemui dalam kenyataan, namun dapat dipastikan bahwa semua model produksi post-fordis selalu berlangsung atas dasar interaksi yang kontinu dan cepat antara produsen dan konsumen. ${ }^{20}$

Kedua, peralihan dari sentralisasi produksi menuju desentralisasi produksi. Dalam model fordis, produksi dilakukan secara terpusat. Tenaga kerja dan pabrik-pabrik diagregasikan ke dalam kota-kota pusat industri. Hal ini dilakukan karena efisiensi dari produksi industrial massal sangat bergantung pada konsentrasi dan kedekatan di antara elemen-elemen produksi. Ada pun dalam model post-fordis, produksi dilakukan secara desentralistis. Model ini bertolak dari premis bahwa efisiensi tidak memi-

sinya, lihat tulisan-tulisan dalam Post-Fordim: A Reader, ed. Ash Amin (Oxford: Blackwell Publishers Ltd. 1994).

20 Michael Hardt and Antonio Negri, Empire, pp. 289-290. 
liki hubungan linier dengan ukuran jarak. Kemajuan teknologi komunikasi dan informasi juga berperan penting dalam hal ini karena melaluinya jarak tidak lagi menjadi hambatan. Komunikasi dan kontrol atas kerja dapat dilakukan dalam jarak yang jauh, dan produk imaterial dapat ditransfer secara cepat dan murah. Pembuatan suatu komoditas dapat dikerjakan melalui berbagai fasilitas produksi yang terpencar namun dikoordinasi secara simultan. ${ }^{21}$

Desentralisasi di atas dimungkinkan karena di dalam produksi postfordis, model organisasional produksinya memiliki bentuk jaringan. Model ini sangat berbeda dengan model perakitan bergilir yang merupakan kekhasan dari produksi fordis. Produksi model lama mensyaratkan sentralisasi kerja dan kedekatan elemen-elemen produksi. Pekerja disatukan dalam satu bangunan pabrik yang sama dan komunikasi hanya dilakukan di antara sesama pekerja yang berdekatan secara fisik. Siklus produksi ditata secara terkoordinir dengan cara menempatkan situs-situs produksi yang saling terkait secara berdekatan untuk meminimalkan ongkos tansportasi dan menghemat waktu produksi. Tambang mineral, misalnya, diletakkan berdekatan dengan pabrik yang mengolah mineral tersebut sebelum didistribusikan ke pasar. Sebaliknya, dalam model produksi post-fordis yang berbentuk jaringan, kedekatan tersebut tidak lagi diperlukan. Melalui jaringan, pekerja yang terlibat dalam proses produksi dapat saling berkomunikasi tanpa memedulikan jarak di antara mereka. Pekerja tidak lagi terikat di dalam satu bangunan khusus yang diperuntukkan untuk bekerja. Mereka dapat saja bekerja di rumah asalkan terhubung dengan jaringan internet. Kerja sama dengan cara demikian disebut "kerja sama abstrak." Kerja sama ini memberikan peranan yang penting pada komunikasi pengetahuan di antara sesama pekerja, tanpa mereka harus melakukan kontak fisik satu sama lain dan tanpa harus saling mengenal. ${ }^{22}$

21 Michael Hardt and Antonio Negri, Empire, pp. 294-295.

22 Michael Hardt and Antonio Negri, Empire, pp. 295-296. 
Kerja imaterial tidak berwajah tunggal. Terdapat dua tipe kerja imaterial. Pertama, kerja yang bersifat intelektual atau linguistik, yang melakukan kegiatan-kegiatan seperti pemecahan masalah, tugas simbolis dan analitis, serta ekspresi linguistik. Produk dari kerja jenis ini di antaranya adalah gagasan, simbol, kode, teks, figur linguistik, gambar, dan halhal sejenisnya. Tipe kerja imaterial yang kedua disebut "kerja afek- tif." Kerja afektif merupakan kerja yang memproduksi atau memani- pulasi pengalaman rasa-merasa, yakni keadaan tertentu yang dialami oleh tubuh atau pikiran seseorang, seperti perasaan senang, sejahtera, puas, tertarik, atau bergairah. Contoh pekerja afektif adalah pengacara, pramugari, dan pelayan restoran. Meski demikian, pembedaan dari dua jenis kerja imaterial tersebut hanya analitis sifatnya. Kebanyakan kerja imaterial yang aktual mengombinasikan dua tipe tersebut. Reporter berita, misalnya, meskipun secara sekilas tergolong sebagai pekerja imaterial linguistik karena memproduksi informasi berupa berita, namun sesungguhnya juga merupakan pekerja imaterial afektif karena ia dituntut untuk menciptakan afeksi dengan cara membuat berita yang disampaikan terasa atraktif dan menarik. ${ }^{23}$

Kerja imaterial membawa perubahan yang signifikan di dalam kondisi kerja. Apabila dalam kerja industrial batasan antara waktu kerja dan waktu luang terbagi dengan jelas, tidak demikian halnya dengan kerja imaterial. Waktu kerja mempunyai tendensi untuk berekspansi sampai ke seluruh waktu hidup pekerja. ${ }^{24} \mathrm{Hal}$ ini dapat dipahami meng- ingat sifat dari kerja imaterial itu sendiri yang tidak terikat oleh waktu. Seorang konsultan yang bertugas memecahkan problem perusahaan yang menjadi kliennya, misalnya, seringkali mendapatkan ide pemecahan masalah di saat-saat yang tak terduga, seperti saat ia sedang mandi atau mau berangkat tidur. Pada titik ini, hidup sesungguhnya tidak lagi terpisahkan dengan kerja. ${ }^{25}$

23 Michael Hardt and Antonio Negri, Multitude, p. 108.

24 Michael Hardt and Antonio Negri, Multitude, p. 111.

25 Maurizio Lazzarato, Immaterial Labor, p. 137. 
Kerja imaterial merupakan kerja yang dipandu oleh norma-norma dasar berupa informasi, komunikasi, dan kerja sama. Kerja sama produktif yang dilakukan tidak lagi berjalan di bawah dikte ketat kapitalis, melainkan berlangsung melalui energi-energi produktif dari pekerja itu sendiri. Satu hal penting yang mencirikan kerja imaterial adalah bahwa kerja ini menciptakan produk yang bersifat sosial dan umum. ${ }^{26} \mathrm{Hal}$ ini demikian karena apa yang diproduksi dalam kerja imaterial, yakni informasi, afeksi, dan pengetahuan, merupakan hal-hal yang bersifat sosial dan umum. Dalam perspektif lain, sifat umum dari kerja imaterial juga disebabkan oleh penggunaan komputer dalam proses produksi secara masif dan lazim. Melalui penggunaan komputer, semua pekerja imaterial dalam berbagai bidang semakin dijauhkan dari objek kerjanya. Memang penjauhan dari objek kerja dengan menggunakan alat juga terjadi dalam kerja industrial, misalnya, dalam penggunaan mesin jahit yang menjauhkan penjahit dari objek kerjanya yang berupa pakaian. Akan tetapi, alat yang digunakan dalam ekonomi industrial sifatnya terberi dan tidak fleksibel. Mesin jahit hanya dapat digunakan secara eksklusif oleh penjahit. Ada pun pada komputer, penjauhan tersebut sifatnya universal karena perangkat tersebut dapat digunakan oleh seluruh pekerja imaterial yang bekerja di berbagai bidang. Itulah sebabnya mengapa komputer disebut juga "alat universal." ${ }^{27}$ Karena berbagai jenis kerja imaterial berbagi sifat yang sama, yakni mengarah kepada "yang umum" (commonality), meskipun tentu dalam derajat abstraksi yang berbeda-beda, sebagai hasilnya terjadi reduksi kualitatif dalam rezim pembagian kerja. ${ }^{28}$

Ketika berbicara mengenai sifat umum dari kerja imaterial tersebut, banyak teoretisi kerja imaterial menyinggung gagasan Marx mengenai intelek umum (general intellect). Marx menggunakan istilah ini dalam Grundrisse untuk merujuk kepada "kapasitas ilmiah" yang terobjektivasikan sebagai kapital tetap, yakni sistem permesinan atau machina machinarum. Akan tetapi, buru-buru dinyatakan bahwa pemahaman seperti

26 Michael Hardt and Antonio Negri, Multitude, pp. 113-114.

27 Michael Hardt and Antonio Negri, Empire, p. 292.

28 Michael Hardt and Antonio Negri, Multitude, pp. 113-114. 
itu tidak lagi memadai dalam konteks produksi post-fordis. Intelek umum dalam dunia post-fordis sekarang mewujud lebih sebagai atribut dari pekerja imaterial. Atribut tersebut adalah, seperti dikatakan Paolo Virno, "repertoar dari inteligensi yang tersebar, merupakan 'partitur musik' yang menciptakan ikatan bersama di antara jaringan jamak." ${ }^{29}$ Kapasitas tersebut di antaranya kompetensi berbahasa, kemampuan untuk belajar, kapasitas untuk melakukan abstraksi dan menjalin hubungan, dan akses kepada refleksi-diri. Di sini kita tidak berbicara tentang sejenis pekerja yang cerdas atau superior, karena kapasitas-kapasitas tersebut merupakan kapasitas umum yang dibagi bersama oleh seluruh pekerja, tidak hanya pekerja imaterial. Intelek umum tidak lain adalah intelek pada umumnya.

Seperti yang telah disebutkan sebelumnya, ekonomi post-moderndan dengannya juga kerja imaterial—kini menempati posisi hegemonis dalam tatanan global. Memang, dalam beberapa negara kapitalis dominan, berbagai statistik menunjukkan bahwa sejak awal 1970-an telah terjadi migrasi pekerja besar-besaran dari sektor industri menuju ke sektor jasa seperti pelayanan kesehatan, pendidikan, keuangan, hiburan, dan periklanan. Namun hal ini bukanlah bukti bahwa ekonomi postmodern telah menjadi hegemonis, sebab dalam kenyataannya, sektor agrikultur dan industri tidak lenyap dan tidak berhenti memainkan peran yang penting. Justru sebaliknya, pekerja agrikultur tetap dominan di banyak negara. Demikian juga pekerja industrial secara global jumlahnya tidak menyusut. Pengamat yang kritis bisa saja menyatakan bahwa ekonomi post-modern mampu menempati posisi dominan di negara kapitalis maju karena ekonomi industrial-manufaktur telah diekspor ke negara-negara berkembang yang harga buruhnya lebih murah. Sesungguhnya, pekerja dalam sektor ekonomi post-modern merupakan minoritas di antara total pekerja global serta terkonsentrasi di dalam bagian kecil dunia. ${ }^{30}$

29 Paolo Virno, "Virtuosity and Revolution: The Political Theory of Exodus," in Radical Thought in Italy, p. 193.

30 Michael Hardt and Antonio Negri, Multitude, p. 109. 
Hegemoni ekonomi post-modern dengan demikian lebih baik dipahami sebagai tendensi. ${ }^{31}$ Sebagai suatu tendensi, hegemoni tersebut tidak dapat dibuktikan atau disanggah melalui data statistik..$^{32}$ Jika demikian, bukti apa yang dapat diajukan untuk menyokong tesis hegemoni ekonomi post-modern? Hardt dan Negri memberikan setidaknya tiga pembuktian kualitatif. ${ }^{33}$ Pertama, kini sektor ekonomi agrikultur dan industrial semakin dijalankan dengan cara yang sesuai dengan kualitas-kualitas pokok yang melekat pada model ekonomi post-modern yang menekankan informasi dan pengetahuan. Sama seperti ketika era modernisasi menyebabkan terjadinya industrialisasi dalam sektor ekonomi lain dan bahkan masyarakat secara umum, demikian juga era post-modernisasi menyebabkan terjadinya informatisasi dan "jasaisasi" dalam seluruh sektor ekonomi dan kehidupan sosial. Agrikultur, misalnya, kini semakin banyak menggunakan inovasi biologis dan biokimia seiring dengan pemanfaatan teknologi-teknologi baru seperti rumah kaca, pemanasan buatan, dan pertanian tanpa tanah. Sektor ini juga semakin akrab dengan isu-isu di seputar hak milik atas informasi genetik yang ada dalam bibit tanaman. ${ }^{34}$ Demikian pula dengan produksi industrial. Kini produksi ini semakin terinformasionalisasikan melalui penggunaan teknologi komunikasi di dalam proses produksinya. ${ }^{35}$ Kedua, semakin dihargainya dimensi imaterial yang termuat dalam sebuah produk. Hal ini muncul melalui fenomena seperti paten, hak cipta, dan produk-produk hukum internasional yang menjadikan barang imaterial sebagai bagian dari hak privat yang dapat dimiliki secara eksklusif oleh seseorang atau sebuah perusahaan. Ketiga, jaringan tersebar yang merupakan ke-

31 Michael Hardt and Antonio Negri, Multitude, p. 107.

32 Michael Hardt and Antonio Negri, Multitude, p. 115.

33 Michael Hardt and Antonio Negri, Multitude, pp. 114-115.

34 Michael Hardt and Antonio Negri, Multitude, p. 112.

35 Sebelumnya, Hardt dan Negri mengategorikan produksi industrial yang terinformasionalisasi ini sebagai bagian dari kerja imaterial. Lih. Michael Hardt and Antonio Negri, Empire, p. 293. Namun belakangan mereka membuang kerja jenis ini sebagai bagian dari kategori kerja imaterial. Hal ini dapat dipahami mengingat bahwa meskipun dibantu dengan teknologi informasi, hasil kerja semacam itu tetaplah berupa produk material. Tentang pengaruh norma-norma kerja imaterial terhadap proses produksi industrial, lih. Maurizio Lazzarato, Immaterial Labor, pp. 140-141. 
khasan dari produksi imaterial kini semakin berkecambah di sekujur kehidupan sosial sebagai cara untuk mengetahui segala hal, mulai dari fungsi saraf sampai organisasi teroris.

\section{KERJA IMATERIAL SEBAGAI MEDIUM EKSPLOITASI BARU DAN CELAH RESISTENSI POLITIK}

Konsep kerja imaterial tidak mengandung konotasi determinisme teknologis seperti yang ditemui dalam analisis Daniel Bell tentang masyarakat post-industrial atau analisis Manuel Castells tentang masyarakat informasi. Konsep ini juga berbeda dengan pemahaman naturalistik tentang kerja yang diiringi dengan pendekatan sensualis-empirisistik terhadap materi seperti yang dapat ditemui dalam teori Andre Gorz tentang metamorfosis kerja dan akhir masyarakat berbasis upahan. Alihalih, konsep kerja imaterial muncul sebagai bagian dari perjuangan sosial pekerja dalam menyikapi kondisi produksi dan organisasional yang dihadapinya di tempat kerja. ${ }^{36}$ Dengan demikian, untuk meminjam istilah Marx, bukan kekuatan produksi yang menjadi fokus di sini, melainkan relasi produksi. Meskipun mengakui arti penting dari teknologi informasi terbarukan seperti para teoretisi masyarakat post-industrial dan masyarakat informasi, namun teknologi tersebut diletakkan dalam matriks relasi sosial yang menentukan penggunaan dan pengaplikasiannya. ${ }^{37}$

Perjuangan sosial tersebut mewujud dalam penolakan para pekerja industrial terhadap regulasi kerja yang berlangsung pada tahun 1970an di negara-negara kapitalis maju. Transformasi model produksi dari fordis ke post-fordis pada sebagiannya disebabkan oleh penolakan tersebut. Pekerja menuntut kebebasan dan fleksibilitas yang lebih di dalam kerja. ${ }^{38}$ Preferensi terhadap kebebasan dan fleksibilitas tersebut diterjemahkan melalui penolakan terhadap kerja reguler yang berlangsung sepanjang usia karir. Di era tersebut, banyak orang yang bekerja hanya selama beberapa bulan, kemudian melakukan perjalanan yang jauh,

36 Thomas Atzert, “About Imaterial Labor and Biopower," pp. 60-61.

37 Bdk. Krishan Kumar, From Post-Industrial to Post-Modern Society, p. 62.

38 Franco Bifo Berardi, "What is the Meaning of Autonomy Today?" http://republicart. net/disc/realpublicspaces/berardi01_en.pdf, p. 2. Diakses tanggal 10 Juni 2013. 
lalu kembali lagi untuk bekerja sementara waktu. Model kerja yang memberi kesempatan bagi orang-orang untuk bekerja sesuai dengan minatnya tersebut tidak memberikan kecemasan bagi para pelakunya sebab era itu ditandai oleh kesempatan kerja penuh (full employment) dan kultur yang egaliter. ${ }^{39}$

Tentu saja gaya hidup di atas tidak dapat dilakukan untuk selamanya. Perkembangan yang terjadi pada tahun 1980-an mengonfirmasi hal ini. Sebagai respons terhadap tuntutan pekerja terhadap fleksibilitas dan kebebasan, pihak kapitalis juga hal yang sama terhadap negara, yakni agar usahanya dapat dijalankan secara bebas dan tanpa kekangan. Sejak inilah, dimulai gelombang pasang neoliberalisme yang dipelopori oleh duet Margaret Thatcher-Ronald Reagan dan kemudian diadopsi oleh semakin banyak negara. Kombinasi antara tuntutan terhadap kerja imaterial dengan tatanan ekonomi-politik neoliberalisme tersebut menjadikan kerja imaterial sebagai sesuatu yang kompleks dan paradoksal: genting sekaligus penuh kemungkinan.

Meskipun ekonomi di era post-fordis berbasis paradigma kerja imaterial, bukan berarti bahwa para pekerja hidup dalam era yang menyenangkan dan memuaskan. Kerja imaterial bukanlah kerja suka-suka yang dapat dilakukan secara santai, fun, rileks, dan tanpa perlu dihantui oleh eksploitasi kapitalis seperti layaknya kerja di era kapitalisme modern. Yang benar justru sebaliknya. Post-fordisme merupakan sebuah fase baru yang lebih berbahaya dalam meningkatkan eksploitasi pekerja oleh kapitalis. Parker dan Slaughter-dalam artikel berjudul Managementby-Stress: The Team Concept in the US Auto Industry seperti dikutip Ritzer dan Goodman-menamakan sistem ini "manajemen dalam ketegangan." Tujuannya adalah merentangkan sistem seperti tali karet hingga ke titik putusnya. Pekerjaan dipercepat melebihi kecepatan sistem perakitan bergilir a la fordisme, menuntut pekerja untuk bekerja secara heroik dalam menyelesaikan gilirannya secepat mungkin. ${ }^{40}$ Sistem post-fordis

39 Franco Bifo Berardi, "What is the Meaning of Autonomy Today?," p. 3.

40 George Ritzer dan Douglas J. Goodman, Teori Sosiologi Modern, Edisi Ke-6 (Jakarta: Kencana, 2004), hlm. 203. 
ditandai secara khas oleh kegentingan dan eksploitasi berlebihan sehingga Berardi menyebut kerja imaterial yang dilakukan dalam sistem ini sebagai hiperkerja (hyper-labor). ${ }^{41}$ Pekerja imaterial tak ubahnya merupakan "proletar intelektual" dalam tatanan ekonomi dewasa ini. ${ }^{42}$ Maka apabila dilihat dari perspektif eksploitasi, hampir tak ada yang berubah dalam era post-fordis. ${ }^{43}$

Bagaimana hal tersebut dapat terjadi? Untuk memahami hal tersebut, perlu dipahami sekali lagi pengertian kerja imaterial. Kerja imaterial adalah kerja yang memproduksi barang-barang imaterial, seperti pengetahuan, informasi, komunikasi, relasi, atau respons emosional. Perhatikan bahwa dalam batasan tersebut sama sekali tidak diimplikasi- kan kemestian mengenai adanya relasi upahan. Dengan kata lain, kerja imaterial adalah kerja dalam pengertian yang generik, yakni kerja apa pun, tanpa peduli apakah sang pekerja melakukannya dalam kerangka kerja upahan atau tidak, asalkan hasil dari kerja tersebut adalah pengetahuan, informasi, komunikasi, relasi, atau respons emosional. Kerja imaterial bukanlah kerja yang dilakukan oleh pekerja dengan kemampuan tinggi atau kecerdasan di atas rata-rata. Kerja imaterial merupakan nilaiguna dari tenaga kerja pada umumnya, bentuk aktivitas yang dilakukan oleh setiap subjek produktif dalam tatanan ekonomi baru. ${ }^{44}$ Dalam pengertian ini, aktivitas yang secara tradisional tidak dipandang sebagai

41 Lih. Franco Bifo Berardi, Precarious Rhapsody: Semiocapitalism and the Pathologies of the Post-Alpha Generation, eds. Erik Simpson and Stevphen Shukaitis (London: Minor Compositions, 2009), pp. 144-145.

42 Maurizio Lazzarato, "Immaterial Labor," p. 136. Fenomena proletar intelektual menunjukkan bahwa pendidikan yang tinggi tidak membantu seseorang untuk menjauhkan dirinya dari penindasan dan eksploitasi berlebihan. Karakteristik kerja yang dihadapinya tidak berbeda jauh dengan yang dihadapi kaum proletar yang bekerja dalam kondisi bahaya seperti pekerja migran atau pekerja tanpa masa depan yang pasti akibat mekanisme subkontrak dan alih daya yang dituntut oleh berbagai organisasi internasional seperti IMF dan Bank Dunia dalam kerangka fleksibilisasi pasar kerja dan program penyesuaian struktural. Pekerja-pekerja semacam ini disebut Guy Standing dengan precariat, gabungan dari kata precarious dan proletariat. Lebih jauh lih. Guy Standing, The Precariat: The New Dangerous Class (London \& New York: Bloomsbury Academic, 2011).

43 Antonio Negri, “An Italian Rupture: Production Against Development," Diacritics 39/3 (2009): 24.

44 Maurizio Lazzarato, Immaterial Labor, p. 135. 
kerja-seperti pekerjaan rumah tangga yang dilakukan oleh ibu rumah tangga - pada hakikatnya termasuk ke dalam kerja imaterial; karena dalam melakukan aktivitas rumah tangga sehari-hari-seperti mengasuh bayi, melayani suami, dan membersihkan rumah—ibu tersebut menciptakan produk yang merupakan kekhasan dari kerja imaterial, seperti penciptaan relasi sosial di antara anggota keluarga dan penciptaan afek berupa rasa nyaman serta dikasihi yang dirasakan oleh anak dan suami. ${ }^{45}$

Locus dari kerja imaterial adalah seluruh tubuh sosial itu sendiri. Kerja imaterial dapat diaktualisasikan di mana-mana, baik di ruang publik maupun privat. ${ }^{46}$ Inilah titik berangkat dari konsepsi kerja imaterial. Pada mulanya pekerja imaterial merupakan kekuatan sosial yang mandiri, baik dalam melakukan pekerjaannya maupun dalam berelasi dengan pihak-pihak lain seperti kalangan bisnis. ${ }^{47}$ Tenaga kerja ini mengaktivasikan diri dengan sangat subtil dalam bentuk hubungan tak terduga antaraliran yang ada dalam jaringan yang terdistribusi dalam tubuh sosial. Jaringan ini memediasi masyarakat untuk melakukan swakomposisi, di mana budaya, seksualitas, penyakit, dan hasrat saling bertarung, bertemu, bercampur, dan secara konstan mengubah lanskap sosial. Menurut Berardi, dalam momen inilah para pekerja sungguh menjadi otonom..$^{48}$

Genealogi dari munculnya eksploitasi dan penindasan terhadap pekerja imaterial dimulai tidak dari sini. Eksploitasi tersebut dimulai ketika pekerja imaterial mengikatkan dirinya ke dalam relasi produksi kapitalis. Ketika pekerja imaterial terjerembab dalam relasi produksi kapitalis, eksploitasi mulai dilancarkan terhadap mereka melalui berbagai manifestasi. Pertama, sebagai akibat dari mudahnya melakukan mobilisasi modal di era ekonomi post-modern, pekerja imaterial terdesak ke dalam posisi tawar yang lemah. Dalam era fordis, modal terikat dalam teritori spesifik tertentu sehingga majikan dipaksa untuk melakukan

45 Bdk. Michael Hardt and Antonio Negri, Multitude, pp. 110-111.

46 Maurizio Lazzarato, Immaterial Labor, p. 136.

47 Maurizio Lazzarato, Immaterial Labor," p. 137.

48 Franco Bifo Berardi, What is the Meaning of Autonomy Today?, pp. 1-2. 
hubungan kontrak dengan pekerja industrial, kadangkala dalam jangka waktu yang lama disertai dengan aneka jaminan. Meskipun seringkali memberi upah yang besar kepada pegawai, namun keuntungan yang tinggi tetap dapat diperoleh majikan karena sistem fordisme mampu melakukan kontrol terhadap setiap proses kerja dan kecepatan kerja. ${ }^{49}$ Di era post-fordis kondisi tersebut tidak dapat lagi dijalankan. Majikan sebagai pemegang modal dapat menghindarkan diri dari kewajiban untuk melakukan negosiasi dengan pekerja karena seiring dengan informatisasi ekonomi, modal dapat dipindahkan ke berbagai belahan dunia secara sekejap. Artinya, pekerja terancam untuk kehilangan pekerjaannya sewaktu-waktu. Bahkan, pelemahan posisi tawar pekerja tersebut dapat dilakukan cukup dengan memanfaatkan potensi mobilitas dari modal tanpa perlu secara aktual memindahkannya ke tempat lain. Sebagai akibatnya, banyak pekerja imaterial yang bekerja dalam kontrak dan kesepakatan yang tidak menguntungkan diri mereka seperti kerja lepas (freelance), kerja rumahan, kerja paruh waktu, atau kerja bayar jadi (piece-work)..$^{50}$

Manifestasi kedua dari eksploitasi pekerja imaterial dalam kerangka relasi produksi kapitalis mewujud melalui transformasi preskripsi dan definisi kerja (jobdesk) menjadi preskripsi subjektivitas. Telah dikatakan sebelumnya bahwa kerja imaterial bertumpu pada prinsip-prinsip dasar berupa kerja sama, komunikasi, kreativitas, dan intelektualitas. Semua itu hanya dapat digunakan secara maksimal ketika pekerja imaterial mendayagunakan subjektivitasnya secara penuh. Dalam pada itu, ketika karakter-karakter khas pekerja imaterial tersebut dilokalisasi ke dalam rezim kerja upahan, maka apa yang sejatinya merupakan fakultas alamiah dan organik berbalik menjadi aturan dan komando. Pekerja yang dibayar oleh kapitalis untuk mengerjakan proyek tertentu dipaksa untuk menjadi subjektif. Dalam melakukan pekerjaannya, secara paradoksal, pekerja "dipaksa untuk kreatif." Pada titik ini, antara majikan dan pekerja mulai

49 Harland Prechel, "Fordism/post-Fordism," in The Blackwell Encyclopedia of Sociology, p. 1769.

50 Michael Hardt and Antonio Negri, Empire, pp. 296-297. 
terdapat ketidakcocokan karena keharusan demikian bertentangan dengan kepribadian dan kebebasan dari pekerja. ${ }^{51}$

Dalam relasi produksi kapitalis juga terjadi transformasi dari sifat komunikasi yang digunakan oleh pekerja imaterial. Dalam "kondisi alamiahnya," yakni dalam jaringan kompleks yang ada dalam tubuh sosial, komunikasi beredar bebas dan bergerak liar secara kontingen. Namun ketika pekerja imaterial terikat dalam relasi produksi kapitalis, komunikasi yang berlangsung di antara mereka dinormalisasi sedemikian rupa sehingga komunikasi tersebut menjadi sesuai dengan imperatif produksi. Hubungan komunikatif, baik secara vertikal maupun horizontal, telah ditentukan sebelumnya baik dalam bentuk maupun isinya. Pekerja menjadi tak lebih sebagai penyiar dan pemantul dari kodifikasi dan dekodifikasi komunikasi yang digariskan kapitalis, di mana pesan ditransmisikan dalam suatu cara yang jernih dan bebas dari ambiguitas..$^{52}$ Ini merupakan pencerabutan dari kapasitas komunikatif murni yang dimiliki pekerja imaterial, yang seharusnya bebas dan tanpa paksaan. Produksi komunikasi yang merupakan kapasitas utama pekerja imaterial kini terlibat secara langsung dalam proses valorisasi, yakni peningkatan nilai kapital. Jika dahulu komunikasi diorganisasikan dengan menggunakan sarana bahasa, ideologi, dan institusi literer/artistik, kini komunikasi ditanamkan dalam proses produksi dan direproduksi dengan menggunakan skemaskema teknologis dalam arahan organisasi dan manajemen produksi. ${ }^{53}$

Dalam seluruh proses tersebut, kapitalis bertindak layaknya parasit yang menempel dalam tubuh pekerja imaterial. Subjektivitas dan daya cipta kreatif yang dimiliki oleh pekerja imaterial diperalat dan dikooptasi agar mereka mau melakukan tindakan yang dimaui oleh kapitalis. Di dalam era post-fordis, eksploitasi pun mengambil bentuk baru. Kapitalis tidak lagi mendapatkan keuntungan dengan menyadap nilai-lebih dari pekerja yang berproduksi untuknya. Kini bahkan tidak lagi relevan untuk berbicara mengenai "hukum nilai" dan hubungan antara waktu

51 Maurizio Lazzarato, Immaterial Labor, p. 134.

52 Maurizio Lazzarato, Immaterial Labor, pp. 134-135.

53 Maurizio Lazzarato, Immaterial Labor, p. 143. 
kerja dan nilai komoditas yang dulu menjadi kesibukan intelektual David Ricardo dan Karl Marx, karena melalui peran penting yang dimainkan kerja imaterial dalam seluruh proses produksi, sirkulasi faktor-faktor produksi menjadi bagian integral dari siklus produksi dan reproduksi komoditas. ${ }^{54}$ Kerja hidup dan kerja mati telah menjadi satu, di mana variabel pekerja menjadi tak dapat dibedakan dengan kapital. ${ }^{55}$ Untuk dapat beradaptasi dengan situasi produksi baru ini, pihak kapitalis pun mengembangkan cara baru untuk mengakumulasi kapital.

Dalam melakukan penggiringan pekerja imaterial ke dalam relasi produksi kapitalis, kapitalis sesungguhnya menghadapi dilema pelik dan ketegangan laten yang tidak dapat dihapuskan. Di satu sisi, kapitalis sesungguhnya terpaksa mempekerjakan pekerja imaterial karena tatanan ekonomi dewasa ini seolah mendiktekan bahwa proses produksi yang paling efektif dan strategis hanya dapat dilakukan oleh pekerja imaterial. Di sisi lain, mereka juga harus berjuang mati-matian untuk mencegah agar kekuatan dan daya yang dimiliki oleh pekerja imaterial tidak diklaim kembali dan dikuasai sepenuhnya oleh pemiliknya. ${ }^{56}$ Ini merupakan hal yang tidak mudah semenjak kekuatan yang ada secara imanen pada pekerja imaterial, yakni kapasitas komunikatif, berpikir, dan membangun relasi sosial, bukanlah hal yang dapat diapropriasi secara mutlak layaknya kapital tetap.

Kerja imaterial mengonstitusikan dirinya secara langsung dalam bentuk kolektif berupa jaringan dan aliran. Instrumentalisasi terhadap jaringan dan aliran tersebut dalam rangka menyadap nilai gunanya untuk perluasan profit oleh kapitalis sama sekali tidak merusak sifat otonomi dari kerja imaterial tersebut. Mengapa? Karena meskipun potensi kerja imaterial dieksploitasi habis-habisan oleh kapitalis, namun setiap aktualisasi dari kerja imaterial selalu terstruktur sebagai peristiwa, yakni proses penciptaan terbuka di antara pekerja dan publik luas yang diorga-

54 Antonio Negri, “An Italian Rupture": 22-23.

55 Antonio Negri, “An Italian Rupture": 24.

56 Maurizio Lazzarato, Immaterial Labor, p. 135. 
nisasikan melalui komunikasi dan kerja sama di antara keduanya. ${ }^{57}$ Kerja sama semacam itu selalu luput dari determinasi logika ekonomi, karena kerja sama tersebut hidup dan dihidupi oleh yang sosial. Kapitalis hanya bisa mengapropriasi bentuk dan produk dari kerja sama tersebut, untuk kemudian menormalisasi dan menstandarkannya. ${ }^{58}$ Namun kapitalis tidak pernah dan tidak akan mampu untuk mengapropriasi kekuatankekuatan produktif yang mewujud dalam aktivitas kognitif, pengetahuan, dan daya cipta dari jaringan jamak yang memproduksi keumuman. ${ }^{59}$ Di titik inilah didapatkan celah untuk melakukan resistensi politik dalam ranah kerja. Pekerja imaterial merupakan subjek mandiri yang mempunyai kekuatan untuk membongkar tata relasi kapitalistik karena kapitalisme sekarang hanya dapat berjalan dan bertahan dengan cara pemanfaatan oportunistik terhadap pekerja imaterial. Dalam tampilan permukaan yang seolah merupakan kelanjutan canggih dari relasi produksi kapitalis awal, secara diam-diam, untuk meminjam terminologi Hegelian, sang budak telah berbalik menjadi tuan. Pekerja imaterial adalah "spesies" baru yang unik yang lahir dalam sejarah tepat pada saat yang genting. Berbeda dengan model-model pekerja yang ada sebelumnya, ia bukanlah sebuah fungsi dalam fase historis tertentu kapitalisme. Alih-alih, ia merupakan produk dari "revolusi sunyi" yang berlangsung di dalam realitas antropologis kerja dan dalam rekonfigurasi makna-makna kerja. ${ }^{60}$

Untuk memahami dengan lebih jernih paradoks yang diidap oleh kapitalisme post-fordis, perlu diperkenalkan perbedaan antara biopower dengan produksi biopolitik. Biopower berkenaan dengan salah satu fitur paling mencolok dari corak kerja di era kapitalisme post-fordis yang bersifat tidak dibatasi ruang. Karena "bahan baku" proses produksi kini dapat ditemui secara masif di dalam kekuatan-kekuatan produktif umum yang terdapat di dalam tubuh sosial dalam bentuk energi komunikatif,

57 Maurizio Lazzarato, Immaterial Labor, p. 144.

58 Maurizio Lazzarato, Immaterial Labor, p. 145.

59 Antonio Negri, “An Italian Rupture," p. 25.

60 Maurizio Lazzarato, Immaterial Labor, p. 139. 
bahasa, dan hubungan-hubungan sosial, maka kapitalisme memperoleh momen historisnya untuk melakukan ekspansi proses produksi. Produksi tidak perlu lagi dipusatkan di dalam pabrik sebab produksi kini dapat dijalankan di dalam semua ruang hingga mencakup totalitas sosial secara umum. Untuk menggambarkan proses ini, masyarakat itu sendiri kini bahkan dialusikan sebagai pabrik. Kekuasaan kapitalis kontemporer dikatakan menunjukkan corak sebagai biopower karena kontrolnya terhadap seluruh kehidupan sosial tersebut. ${ }^{61}$ Karena kekuatan biopower merengkuh segalanya, maka kini tidak ada lagi yang berada di luar kapital. ${ }^{62}$

Biopower tersebut dipertentangkan dengan produksi biopolitik. Apabila biopower merupakan kekuatan yang berada di atas masyarakat, transenden sebagai otoritas berdaulat yang menimpakan tatanan kepada masyarakat secara keseluruhan, maka produksi biopolitik adalah kekuatan produktif yang terdapat secara imanen di dalam masyarakat. Produksi biopolitik termanifestasikan melalui kerja kolektif yang menciptakan relasi-relasi dan bentuk-bentuk sosial. ${ }^{63}$ Hardt dan Negri menulis: “...Produksi biopolitik merujuk pada situasi di mana mekanisme kerja sama, komunikasi, dan kolaborasi telah terjadi di dalam kerja itu sendiri. Ini membawa terciptanya peluang baru untuk menjalankan swamanajemen ekonomi dan swa-organisasi sosial dan politik." ${ }^{64}$ Karena adanya kekuatan terpendam berupa produksi biopolitik inilah Autonomia berani mengatakan bahwa kapitalisme mutakhir berada pada posisi yang rentan. ${ }^{65}$

61 Antonio Negri, “An Italian Rupture,” p. 21. Sebagai catatan, biopower merupakan konsep yang diciptakan oleh Michel Foucault untuk menggambarkan strategi kekuasaan yang dikembangkan pada akhir abad ke-18 yang bertujuan untuk mengontrol dan meregulasi populasi secara umum. Lih. Michel Foucault, The History of Sexuality, Vol. 1: An Introduction (New York: Vintage, 1990) dan Society Must Be Defended: Lectures at the Collège de France, 1981-1982 (New York: Picador, 2003).

62 Michael Hardt and Antonio Negri, Multitude, p. 102.

63 Michael Hardt and Antonio Negri. Multitude, pp. 94-95.

64 Michael Hardt and Antonio Negri, Multitude, p. 336.

65 Pembahasan tentang produksi biopolitik dapat dilihat dalam karya bersama Hardt dan Negri yang terakhir, Commonwealth (Cambridge: The Belknap Press of Harvard University Press, 2009), pp. 345-355, 363-367. 
Sebagai salah satu kekuatan yang dapat digunakan untuk mensubversi kapitalisme dari dalam, produksi biopolitik hendaknya dilengkapi dengan strategi perlawanan lain yang disebut dengan penolakan atas kerja (refusal of work). Ini merupakan gagasan lama yang diformulasikan pertama kali pada tahun 1964 oleh Mario Tronti ${ }^{66}$ dan yang menjadi tema utama pemikiran gerakan Autonomia pada tahun 1960-an sampai awal tahun 1970-an. Apa yang dimaksud dengan istilah penolakan atas kerja tentu saja bukanlah penolakan atas kerja per se, yakni kerja sebagai aktivitas kreatif atau produktif, karena hal itu akan bertentangan dengan sifat dasar kemanusiaan. Istilah ini juga bukan merupakan promosi terhadap kemalasan, kesantaian, atau liburan. ${ }^{67}$ Alih-alih, penolakan atas kerja dimaksudkan sebagai penolakan atas kerja di dalam tatanan relasi produksi kapitalis. ${ }^{68}$ Negri menulis:

Ketika eksploitasi telah mencapai titik di mana eksploitasi tersebut juga dirasakan pada level sosial, dengan alienasi di mana-mana, maka dalam rangka melawan eksploitasi dan dominasi, orang harus melakukan perlawanan terhadap kerja, terhadap industri, dan terhadap masyarakat. ${ }^{69}$

Manuver ini mau membebaskan produksi yang berlandaskan prinsip "manusia untuk manusia" yang solider dan komunal dari cengkeraman aturan main produksi kapitalis. Modus produksi yang menolak untuk terlibat dalam sirkuit infinitas valorisasi kapital disebut juga oleh Negri sebagai produksi yang melawan pembangunan. ${ }^{70}$ Penolakan atas kerja mau menyelamatkan dan mengafirmasi kekuatan kreatif dan produktif yang menjadi dasar dari kerja itu sendiri dengan cara membuatnya mandiri dari relasi produksi kapitalis.

Konsep lain yang terkait erat dengan penolakan atas kerja adalah eksodus. Istilah yang segera mengingatkan pada narasi biblis mengenai

66 Sylvere Lotringer and Christian Marazzi, “The Return of Politics," p. 16.

67 Antonio Negri, “An Italian Rupture,"p. 24.

68 Michael Hardt, "Introduction," p. 1.

69 Antonio Negri, "An Italian Rupture," p. 24.

70 Antonio Negri, “An Italian Rupture,” pp. 23-24. 
pelarian diri orang-orang Yahudi dari penindasan Firaun ini diadopsi para pemikir Autonomia sebagai perpanjangan logis dari strategi penolakan atas kerja. Jika penolakan atas kerja merupakan ketegasan sikap yang menolak untuk menundukkan kapasitas kreatif dan otonom dari kerja terhadap pendiktean relasi produksi kapitalis, eksodus merupakan penolakan dalam tataran yang lebih umum, yakni sebagai penolakan terhadap relasi sosial kapitalis secara keseluruhan. Melalui eksodus, totalitas sosial yang dimediasi oleh norma-norma kapitalisme ditolak secara kategoris. Penolakan tersebut dilakukan bukan dengan cara konfrontasi dan oposisi langsung, melainkan dengan cara menarik diri. Eksodus beroperasi dengan logika pengurangan. Kapitalisme dihancurkan tidak dengan pukulan telak di kepala, tetapi dengan penarikan diri besarbesaran pada basisnya, yang merupakan sarananya untuk mempertahankan diri. ${ }^{71}$

Akan tetapi eksodus bukanlah sekadar penyingkiran atau penarikan dari kapitalisme. Ketika sekelompok orang menarik diri dari suatu ruang lama, pada saat yang bersamaan mereka memasuki suatu ruang baru. Eksodus adalah suatu pergerakan untuk memasuki suatu ruang baru dengan aturan main yang berbeda sepenuhnya dengan ruang lama. Apabila Virno menyebut ruang baru tersebut sebagai Republik, ${ }^{72}$ Hardt dan Negri menyebutnya sebagai "komunisme spontan dan elementer."73

Visi revolusi politik yang dirumuskan oleh Autonomia sesungguhnya merupakan visi demokrasi yang radikal. Demokrasi tersebut merupakan demokrasi yang menjadikan kepemilikan sosial terhadap barang-barang umum sebagai prinsip utamanya. Inklusif dalam visi tersebut adalah penolakan terhadap segala jenis hierarki dan kompetisi. Hal ini hanya dapat dicapai melalui pelembagaan keumuman dalam suatu konstruksi pemerintahan partisipatoris yang didasarkan pada spirit kerja sama,

71 Paolo Virno and Michael Hardt, "Glossary of Concepts," in Radical Thought in Italy, pp. $260-261$

72 Paolo Virno, "Virtuosity and Revolution: The Political Theory of Exodus," p. 196.

73 Michael Hardt and Antonio Negri, Empire, p. 294. 
dengan kapasitas untuk mempromosikan dan menyerap komunitaskomunitas baru para produsen. ${ }^{74}$

\section{JARINGAN JAMAK SEBAGAI AGEN REVOLUSIONER BARU}

Sebagai syarat untuk melakukan tindakan revolusioner dalam bentuk penolakan atas kerja dan eksodus, pekerja imaterial perlu untuk secara bersama-sama mengonstitusikan diri sebagai subjek politik yang disebut dengan jaringan jamak (multitude). Siapakah yang dimaksud dengan jaringan jamak? Negri mengatakan bahwa jaringan jamak bu- kan sesuatu yang dapat ditunjuk secara tegas karena jaringan jamak bukanlah konsep yang jelas dengan sendirinya. Jaringan jamak merupakan sebuah proyek politik yang perlu diusahakan dan diciptakan dalam sebuah perjuangan bersama. ${ }^{75}$ Namun demikian, terdapat suatu tolok ukur minimum untuk mengidentifikasi siapa yang dimaksud dengan jaringan jamak. Bagi Hardt dan Negri, semua orang yang bekerja di bawah aturan kapital merupakan orang-orang yang paling mungkin untuk membentuk jaringan jamak tersebut karena mereka secara potensial merupakan kelas yang menolak aturan kapital. Dengan demikian, jaringan jamak terdiri atas orang-orang yang memiliki kepentingan sekaligus kesempatan untuk melakukan resistensi terhadap kapitalisme. Jaringan jamak lebih luas dari kelas pekerja atau proletariat seperti yang biasa dipahami pada abad ke-19 dan ke-20, yakni para pekerja upahan atau buruh yang bekerja di sektor industrial. ${ }^{76}$ Meskipun pekerja imaterial merupakan pekerja yang hegemonis di era mutakhir ini, ia tidak menempati posisi privilese sebagai pemimpin dari orang-orang tertindas. Pekerja imaterial, bersama dengan pekerja industrial, petani, pengangguran, pekerja informal, pekerja reproduktif rumah tangga, dan semua orang miskin, saling melakukan komunikasi dan kerja sama serta membentuk diri sebagai jaringan jamak.

74 Antonio Negri, “An Italian Rupture,” p. 25.

75 Michael Hardt and Antonio Negri, Multitude, p. 104.

76 Michael Hardt and Antonio Negri, Multitude, pp. 106-107. 
Untuk memahami konsep jaringan jamak tersebut dengan lebih baik, perlu dibedakan antara jaringan jamak dengan rakyat (people). Rakyat merujuk pada kesatuan. Meskipun segenap individu yang tergolong sebagai rakyat menunjukkan perbedaan antara satu dengan yang lain, namun begitu mereka bergabung ke dalam kategori rakyat, maka perbedaan tersebut akan disintesiskan atau direduksi menjadi satu identitas tunggal. Sementara jaringan jamak bersifat plural, yakni tidak dapat dileburkan menjadi kesatuan identitas. Jaringan jamak terdiri dari seperangkat singularitas, yakni subjek sosial yang memiliki perbedaan yang tidak dapat direduksi menjadi kesamaan, perbedaan yang tinggal tetap sebagai perbedaan. Namun demikian, jaringan jamak juga berbeda dengan kategori lain seperti keramaian, massa, dan gerombolan. Kategorikategori tersebut adalah kolektivitas yang bersifat fragmentaris, anarkis, dan inkoheren. Masing-masing dari konstituennya tidak berbagi karakteristik yang sama seperti halnya jaringan jamak. Mereka juga bukanlah singularitas sehingga dapat dengan mudah kolaps menjadi keseluruhan yang indiferen. Mereka bersifat pasif sehingga membutuhkan pemimpin yang memanipulasi mereka agar dapat bergerak menciptakan efek-efek sosial yang seringkali destruktif. ${ }^{77}$

Jaringan jamak merupakan singularitas yang bertindak dalam kebersamaan. Dalam rumusan ini, tidak ada kontradiksi antara singularitas dengan keumuman. ${ }^{78}$ Jaringan jamak merupakan tantangan utama bagi kedaulatan yang merupakan salah satu konsep utama dalam filsafat politik, karena kedaulatan bertolak dari prinsip kesatuan. Dalam berbagai tradisi sistem politik yang berbeda-beda, yang berdaulat selalu dikonsepsikan sebagai kesatuan, entah itu monarki, partai, rakyat, atau individu. Kedaulatan selalu dikonstruksikan sebagai kepala dari tubuh politik yang memberi perintah yang harus dipatuhi oleh organ-organ tubuh lainnya. Semua imajinasi kedaulatan ini runtuh di hadapan jaringan jamak. Sebagai singularitas yang tak tersatukan, jaringan jamak secara inheren adalah penyimpangan dan penolakan terhadap kedaulatan.

77 Michael Hardt and Antonio Negri, Multitude, pp. 99-100.

78 Michael Hardt and Antonio Negri, Multitude, p. 105. 
Namun pada dirinyalah demokrasi, sebagai sistem politik untuk semua dan oleh semua, dinyatakan secara tegas, sebab meskipun masing-masing memiliki perbedaan yang tak tereduksikan, mereka dapat bertindak dalam kebersamaan dan mampu memerintah dirinya sendiri. ${ }^{79}$

Kapital ingin menjadikan jaringan jamak sebagai satu kesatuan seperti halnya negara ingin menjadikannya sebagai rakyat. Namun ketika jaringan jamak terpenjara dan tertanam ke dalam tubuh kapital global, pada saat yang sama jaringan jamak juga mendapati dirinya berada di luar proses globalisasi kapitalis. Melalui produksi biopolitik via jaringan jamak, terbuka kesempatan untuk melakukan mobilisasi atas keumuman yang dibagi bersama dan diproduksi oleh jaringan jamak dalam suatu cara yang melawan kekuatan imperial dari kapital global. Dengan bergerak di dalam pembuluh darah kapitalisme, jaringan jamak meloloskan diri menuju ranah baru yang membebaskan, ranah yang memungkinkan jaringan jamak untuk bertindak secara otonom dan memerintah dirinya sendiri. ${ }^{80}$

Sifat kolektif jaringan jamak merupakan hal yang niscaya karena perbudakan eksploitatif dalam dunia post-fordis selalu dilancarkan terhadap kompleks kerja sama yang dilakukan oleh kolektivitas pekerja imaterial, bukannya pekerja perorangan. Sebelumnya telah dikatakan bahwa kerja imaterial merupakan produksi yang bersifat umum. Kerja ini dijalankan dengan sarana dan mediasi keumuman dan hasil akhirnya adalah keumuman juga. Kapitalisme hari ini adalah kapitalisme khalayak (capitalism of the common). Tidak ada produksi kecuali produksi yang dilakukan oleh khayalak dari khalayak (by the common out of common). ${ }^{81}$ Penolakan atas kerja dan eksodus merupakan ekspresi yang memberikan wajah politik bagi keumuman tersebut.

79 Michael Hardt and Antonio Negri, Multitude, p. 100.

80 Michael Hardt and Antonio Negri, Multitude, p. 101.

81 Antonio Negri, “An Italian Rupture,” p. 25. 


\section{PENUTUP}

Penulis telah menyajikan pemikiran para pemikir kunci Autonomia mengenai kerja imaterial dan berbagai konsep kunci yang merupakan implikasi darinya. Sebagai aliran pemikiran (neo-) Marxis yang berasal dari Italia, gagasan-gagasan dari Autonomia banyak dikedepankan dewasa ini. Berbagai kondisi kontemporer seolah memberikan bukti yang kuat bahwa apa yang dipikirkan dan direnungkan oleh para pemikir Autonomia kini menunjukkan gejala yang semakin nyata dan luas, sebagaimana tampak dalam hegemoni kerja imaterial dewasa ini.

Melalui gagasan yang diusung para eksponennya, Autonomia membersitkan optimisme dan penghiburan bagi kita dalam memandang dan meramalkan masa depan tatanan global. Kapitalisme memang terasa semakin hegemonik dalam masyarakat karena dirinya telah merembes ke segala bidang kehidupan dan mengkomodifikasi segala hal. Namun serentak dengan itu, kapitalisme sesungguhnya sedang masuk ke dalam fase yang membahayakan dirinya sendiri, yakni suatu fase di mana pekerja imaterial yang memiliki potensi besar untuk membebaskan diri dari jerat kuasa kapital berperan sebagai penyokong kapitalisme yang paling diandalkan. Untuk mempercepat proses pembebasan tersebut, para pemikir Autonomia pun merumuskan strategi-strategi perlawanan seperti penolakan kerja dan eksodus. Alternatif dari kapitalisme yang diimpikan oleh Autonomia adalah sejenis demokrasi radikal yang bebas dari logika kapitalisme yang selalu mengedepankan yang privat di atas yang publik. Keumuman, kepublikan, solidaritas, kesetaraan, dan kemandirian menjadi norma-norma kunci yang menstrukturisasi relasi sosial dalam sebuah tatanan politik yang ideal. Dengan menjadikan nilainilai tersebut sebagai ukuran ideal, apa yang ditolak oleh kaum Autonomia bukan saja kapitalisme, melainkan juga negara; karena eksistensi negara niscaya meletakan nilai-nilai yang bertentangan dengan aspirasi Autonomia, seperti hierarki dan representasi, yang menghambat aksi-aksi langsung serta membungkam suara-suara otentik dari subjek-subjek singular yang unik dan kreatif. Karena penolakannya terhadap negara 
tersebut, tak mengherankan apabila banyak yang menyebut visi politik kaum Autonomia sebagai neo-anarkis.

Terhadap proposal yang mereka tawarkan, mungkin akan segera timbul pertanyaan: apakah anarkisme merupakan tatanan yang dapat dipraktikkan secara nyata mengingat asumsinya yang terlalu optimis mengenai sifat-sifat dasar manusia dan hubungan sosial? Bagaimana mengatasi problem-problem praktis seperti koordinasi terhadap jaringanjaringan desentralis apabila otoritas dan kekuasaan ditolak sepenuhnya? Dan apakah penghancuran kapitalisme dari dalam melalui penolakan kerja dan eksodus sesungguhnya tak lebih dari penarikan diri ke dalam sebuah perkumpulan-perkumpulan mandiri yang eksentrik dan keras kepala, sembari membiarkan kapitalisme melanggengkan dirinya dengan cara menindas mereka yang tak kunjung tersadarkan dan mau melawan? Jawaban dari pertanyaan-pertanyaan tersebut memang sangat menarik untuk didiskusikan, namun itu semua tidak mengurangi sumbangan dari pemikiran Autonomia dalam membantu kita untuk membaca tatanan kapitalisme hari ini dan menuntut kita untuk bersamasama berpikir guna mengubah keadaan menjadi lebih ideal.

\section{DAFTAR RUJUKAN}

Amin, Ash, ed. Post-Fordim: A Reader. Oxford: Blackwell Publishers, 1994.

Atzert, Thomas. "About Immaterial Labor and Biopower." Capitalism, Nature, Socialism 17/1 (2006): 58-64.

Baca, George. "Legends of Fordism: Between Myth, History, and Foregone Conclusions." Social Analysis 48/3 (2004): 169-178.

Balakrishnan, Gopal, ed. Debating Empire. London and New York: Verso, 2003.

Berardi, Bifo Franco. Precarious Rhapsody: Semiocapitalism and the Pathologies of the Post-Alpha Generation, eds. Erik Simpson and Stevphen Shukaitis. London: Minor Compositions, 2009.

. "What is the Meaning of Autonomy Today?" http:// republicart.net/disc/realpublicspaces/berardi01_en.pdf. Diakses tanggal 10 Juni 2013. 
Bernard, Mitchell. "Post-Fordism, Transnational Production, and the Changing Global Political Economy." In Political Economy and the Changing Global Order, eds. Richard Stubbs \& Geoffrey R. D. Underhill. Hampshire \& London: Macmillan, 1994.

Foucault, Michel. The History of Sexuality, Vol. 1: An Introduction. New York: Vintage, 1990.

- Society Must Be Defended: Lectures at the Collège de France, 1981-1982. New York: Picador, 2003.

Hall, Stuart. “Brave New World.” Marxism Today (October 1998): 2429.

Hardt, Michael. "Introduction: Laboratory Italy." In Radical Thought in Italy: A Potential Politics, eds. Paolo Virno and Michael Hardt. Minneapolis and London: University of Minnesota Press, 1996.

Hardt, Michael and Antonio Negri. Commonwealth. Cambridge, MA: The Belknap Press of Harvard University Press, 2009.

. Empire. Cambridge, MA, and London: Harvard University Press, 2000.

- Labor of Dionysus: A Critique of the State-Form. Minneapolis and London: University of Minnesota Press, 1994.

- Multitude: War and Democracy in the Age of Empire. New York: Penguin Press, 2004.

Harvey, David. The Condition of Postmodernity: An Enquiry into the Origins of Cultural Change. Oxford: Blackwell, 1990.

Haug, Wolfgang Fritz. "Immaterial Labour." Historical Materialism 17 (2009): 177-185.

Kiely, Ray. "Globalization, Post-Fordism and the Contemporary Context of Development." International Sociology 13/1 (1998): 95-115.

Kumar, Krishan. From Post-Industrial to Post-Modern Society: New Theories of the Contemporary World. Second Edition. Malden, Oxford, \& Victoria: Blackwell Publishing, 2005.

Lazzarato, Maurizio. "Immaterial Labor." In Radical Thought in Italy: A Potential Politics, eds. Paolo Virno and Michael Hardt. Minneapolis and London: University of Minnesota Press, 1996.

Lotringer, Sylvere and Christian Marazzi. “The Return of Politics." In Autonomia: Post-Political Politics, eds. Sylvere Lotringer and Christian Marazzi. New York: Semiotext(e), 1980. 
Marazzi, Christian. Capital and Language: From the New Economy to the War Economy. Los Angeles: Semiotext(e), 2008.

Negri, Antonio. "An Italian Rupture: Production Against Development." Diacritics 39/3 (2009): 21-27.

Prechel, Harland. “Fordism/post-Fordism." In The Blackwell Encyclopedia of Sociology, ed. George Ritzer. Malden, Oxford, and Victoria: Blackwell Publishing, 2007, p. 1769.

Ritzer, George dan Douglas J. Goodman. Teori Sosiologi Modern. Edisi ke-6. Jakarta: Kencana, 2004.

Standing, Guy. The Precariat: The New Dangerous Class. London \& New York: Bloomsbury Academic, 2011.

Virno, Paolo. "Virtuosity and Revolution: The Political Theory of Exodus." In Radical Thought in Italy: A Potential Politics, eds. Paolo Virno and Michael Hardt. Minneapolis and London: University of Minnesota Press, 1996.

Zanini, Adelino. "On the 'Philosophical Foundations' of Italian Workerism: A Conceptual Approach." Historical Materialism 18 (2010): 39-63. 